\title{
Cooperative Learning (CL) as a Learning Model for Darmasiswa Students in Developing Indonesian Language Competency
}

\author{
Ana Rosmiati \\ Visual Communication Design Program, Faculty of Fine Arts and Design \\ Indonesian Institute of the Arts Surakarta
}

\begin{abstract}
Darmasiswa was a learning program about art and culture in Indonesia. This program was openedto all foreign students who had an interest in learning about art and culture in Indonesia. Darmasiswa program was regularly held every year. The purpose of Darmasiswa Program was to introduce Indonesian arts and culture to the world through foreign students who had an interest in attending lectures about art and culture in the colleges organizing Darmasiswa program that had been appointed by the Directorate of Higher Education. There were a number of art colleges in Indonesia which were designated as Darmasiswa learning centers. The main requirement that must be fulfilled by Darmasiswa students when choosing a program implemented in Indonesian was to have the willingness to learn Indonesian. If they chose an international program, they do not have to master Indonesian. To expedite the process of learning Indonesian, each Darmasiswa organizing tertiary institution had instructors for foreign students (BIPA). One learning model that could be developed in Indonesian language learning activities was using the Cooperative Learning (CL) model. Each Darmasiswa student in the learning process needed a learning group that helped each other and motivated them to follow learning materials both in class and outside. This cooperative learning model was more suitable to be applied in learning Indonesian, especially when communicating using Indonesian. Additional vocabulary of the Indonesian language was easily memorized with group learning methods.
\end{abstract}

Keywords: Darmasiswa, cooperative learning, model, art, culture.

DOI: $10.7176 / J L L L / 61-05$

Publication date:October $31^{\text {st }} 2019$

\section{INTRODUCTION}

Darmasiswa was one of the programs organized by the Embassy of the Republic of Indonesia through the Bureau of Planning and International Cooperation. This program aimed to introduce Indonesian culture to the world. This program was openedto all foreign students who had an interest in learning about art and culture in Indonesia. Darmasiswa program was regularly held every year. The Darmasiswa program aimed to introduce Indonesian art and culture throughout the world through foreign students who had an interest in attending lectures on art and culture in the colleges organizing the Darmasiswa program. This program was implemented through various mechanisms and regulations that had been set by the Darmasiswa program manager at its main office. The university organizing Darmasiswa program must had prepared a study program that could be used by Darmasiswa students to learn art and culture. Foreign students who were interested in joining Darmasiswa program must at least be able to communicate in Indonesian at the organizing tertiary institution except those participating in the international program.For this reason, in the initial period of arrival, before Darmasiswa students entered the learning process, they were required to attend intensive language study classes for approximately three months. There were several Indonesian language instructors for foreign students (BIPA) who will provide Indonesian language material to support fluency in the teaching and learning process. Darmasiswa program will last for a year. There were several classes that would be prepared such as regular classes, special classes, and application classes that would be held during the learning process of art and culture. The instruction language and the communication language in the learning process used in Darmasiswa program was Indonesian. Requirements that must be fulfilled by Darmasiswa students who took Indonesian language classes were the ability to master the use of Indonesian both in communication and during the learning process.Darmasiswa students must master Indonesian language properly and correctly so that the learning process in class run well. However, the implementation of this program was not easy. Indonesian language instructors worked extra hard in three months to teach Indonesian. So, the right model, media, and strategy were needed for the success of this program. The main obstacle was the language that was the medium of instruction between the languages of their respective countries and Indonesian. Therefore Indonesian language instructors for foreign students were also required to have good competence in terms of mastering English. If all Indonesian language instructors for foreign students had good English competency then it was possible to reduce problems in organizing Darmasiswa program at each of the organizing tertiary institutions.

There were many obstacles that were present during the learning process if the Indonesian language skills of Darmasiswa participants were not good enough. The organizing university had also provided effective programs to overcome the obstacles of Darmasiswa students in mastering Indonesian. Starting from the 
participation for three months in a special class, only learn Indonesian from vocabulary, spelling, to being able to make the most practical communication. But it turned out that a special time allocation of three months to learn Indonesian could not produce satisfactory results.

Some problems arose during the reception and the learning process took place in Darmasiswa program. There were no national standard regulations in all universities implementing Darmasiswa program that could be used as a measurement when receiving Darmasiswa students. These standards could be in the form of language skills, motivation, competence, and so on. Several universities organizing the Darmasiswa program turned out to face very complex and crucial problems. The example was the motivation of Darmasiswa students in certain fields. But not all students behaved like that; there were also those who had real motivation to study art and culture in Indonesia. To overcome this problem, many improvements had been made in terms of the rules of discipline during Darmasiswa program. A problem that was no less crucial was the problem of national regulation on the art and culture curriculum which was applied in all art and culture colleges throughout Indonesia. The curriculum applied to Darmasiswa students was the art and culture curriculum because the target was to introduce Indonesian culture to the world. Darmasiswa students could help introduce Indonesian arts and culture in their respective countries when they returned to their country.

Several campuses related to learning arts and culture at each tertiary institution had prepared types of study programs to choose from. For example, the Indonesian Institute of Art Surakarta, this campus has prepared study programs including Dance, Pedalangan, Karawitan, Batik, Keris, Craft, and Fine Arts. Implementation of Darmasiswa program could actually be used as a kind of trial to see the level of success in organizing lectures for foreign students. The program was also to ensure that the implementation of arts and culture curriculum could be effectively applied to foreign students. To support this program, a national level art and cultural curriculum regulation was needed as a reference for organizing Darmasiswa activities.

The art and culture curriculum in Darmasiswa program was adapted to the conditions and environment of each tertiary institution. The arts and culture curriculum must be assessed according to the level of difficulty faced by students. As in Indonesian Institute of the Arts Surakarta there were several study programs designated for Darmasiswa program classes, such as Karawitan, Ethnomusicology, Pedalangan, Theater, Dance, Batik, Craft, Fine Arts, and Keris. Art and culture material offered was to study traditional arts. Through various considerations, traditional arts were the kind of cultures that must be maintained and preserved in an art college.

Indonesian language had a vital role in supporting the success of Darmasiswa program. The language served as the main tool to communicate both within the scope of education and when dealing with others. Indonesian language instructors for foreign students (BIPA) would strive for appropriate learning methods to accommodate students's interests. One of the efforts made was to determine the right model in learning. The work done was still considering various aspects that were appropriate in creating the foundation of learning. These aspects included the language skills of Darmasiswa participants, teaching resources, learning support laboratories, and so on. After making observations every year, there needed to be an evaluation regarding the implementation of Darmasiswa program. Therefore the Cooperative Learning model was considered as one of the more appropriate methods in conveying Indonesian language learning material.

The cooperative learning model was more suitable to be applied in Darmasiswa student learning system. This was because the Darmasiswa program required learning-groups that helped and motivated each other to follow the learning process both in the classroom and outside. This model was more suitable to be applied in learning Indonesian language, especially when communicating using Indonesian language. Understanding Indonesian vocabulary was also easier with group learning methods. The example was when students were given the task of understanding texts in Indonesian. This task would be easier if done in groups. Likewise, when students must make short stories based on daily experience using Indonesian.

Language was an effective communication tool between humans. In a variety of situations, language could be used to convey the speaker's ideas to the listener, or writer to the reader. Of course, in each situation, the communication faced was one of several variations of language users. The use of language in the inter-buyer market, between buyers and sellers, or between sellers, must be different from speaking in front of respected people, between superiors and subordinates, between patients and doctors, between students and teachers, between attendees of official meetings, and so on. Each situation allowed one to choose the language variations to be used. The factors of speaker, listener, subject matter, place, and atmosphere of conversation, influenceed an individual in choosing variations in language (Sugihastuti, 2000: 8).

Winataputra (2005: 1) said that the instructor or lecturer is a person who is very influental in organizing the learning process in class. The class consists of a number of students who are guided by instructors to explore the world and learn how to direct the results of exploration to provide benefits. Instructors certainly expect that students can understand the social world, develop self-confidence, and always improvd self-quality. These things are important goals for instructors.

Guntur (2010:7) argued that education is a systematic process to enhance human dignity holistically, which enables the three most menial dimensions of humanity above to develop optimally. Thus, education should be a 
strategic vehicle for the development of all individual potentials, so that the ideals of prosperity for all Indonesian people can be achieved. Based on the basic conceptions mentioned above, and in accordance with the vision, mission, and objectives of ISI Surakarta, some values developed include core ethical values, professional values, and selected professions. The development of core ethical values includes: trustworthiness, respect, responsibility, fairness, care, and citizenship. The development of professional values includes values that develop among individuals, professions, cultures and professional norms. Professional values also include skills, intelligence, discipline, law abiding, performance, independence, confidence, and responsibility. While the development of selected professional values is related to the interests of students, which includes: cognition, emotions, and developing observations of experiences that have been experienced.

1. Abstract conceptualization, is creating a concept or theory to explain the results of observation.

2. Active experiments, is using theories to solve a problem and make a decision.

These four aspects of learning formed a learning cycle. However, it did not mean that a person learned through these four aspects, but rather resembled a door that someone could enter when learning. Based on experience, someone might prefer to start learning from one particular aspect rather than starting from other aspects.

\section{METHODS}

This qualitative research used a method that emphasized aspects of understanding. The nature of the research was descriptive by analyzing the problem in depth. Data obtained from observations, interviews, and documentation of selected informants. Informants were chosen in a chain to further deepen the data. Qualitative data collection techniques were obtained from observing Darmasiswa students at ISI Surakarta as research objects. Observation was conducted in two ways, i.e. direct and indirect observation. When conducting direct observation, researcher observed objects such as during the learning process in class. Likewise, research was also carried out when students participated in learning outside the classroom. Several times Darmasiswa students were also asked to visit historic cultural sites in Surakarta. Historical places in Surakarta includedPasar Gedhe, Surakarta Palace, Lokananta, Pasar Klewer, Mangkunegaran, and so on. Interviews with Darmasiswa students were also carried out with written notes and audio visual recordings. Researcher also held interviews with Darmasiswa students between out-of-classroom activities to obtain information. Indirect observations were made through recordings during out-of-learning-session activities, for example during practical exercises.

\section{RESULT AND DISCUSSION}

\subsection{Introduction of Indonesian People's Habits}

The implementation of a special class studying Indonesian for three months that was targeted to students of the Darmasiswa Program did not all give satisfactory results. There were indeed some students who could communicate fluently using Indonesian. In fact, there were those who continued to study at bachelor's level (S1) and planned to pursue their master's degree (master program). This was certainly a very encouraging fact for BIPA instructors, especially Indonesian language instructors for foreign students. To optimize BIPA learning, Darmasiswa participants were first introduced to the systems and habits of the people in Indonesia. This was an important matter, so that they could understand the conditions of social life in Indonesia. Therefore this step was the first step when Darmasiswa students came to Indonesia. Darmasiswa participants who had been placed at each tertiary institution in Indonesia would be picked up by the Darmasiswa program manager. Furthermore, the program manager would find a suitable housing for Darmasiswa participants. Usually it was located not far from campus and was easily transported. Before entering into the learning process, Darmasiswa students were equipped with a variety of knowledge about Indonesianculture; from customs, patterns of life, social, order in the community, and so on, including also how to dress when attending college.

Managers and instructors of Darmasiswa made an agenda to visit several cultural sites, traditional villages, studios, and historical objects in the city. Foreign students tended to choose to study in Solo, Yogya, and Bali whose cultural traditions and art were still well maintained. For example in Solo, they were invited to visit the Palace, Batik Laweyan village, museums, traditional dance studios, Pasar Gedhe, and so on. Visiting these places helpedforeign students in learning Indonesian language. BIPA instructors gave assignments to Darmasiswa students to re-describe places visited in Indonesian-language text. Tasks were conducted in groups or individually. The instructorevaluated after students presented in front of the class. This method trained students to be able to communicate properly and correctly using Indonesian. Language and culture formed a synergy in the learning system for Darmasiswa students. The nature of the language that was universal and dynamic could be a pillar for the culture that existed in Indonesia. Culture that always developed along with the increasing development of civilization in the world made language as the delivering medium. Then the two could go hand in hand with a dynamic of human life.

Indonesian language learning was also inserted in a number of art and culture courses. Here was one example of the art and culture curriculum at the Indonesian Institute of the Art, Surakarta. 
3.1. 1. Performing Arts, 6 months program

\begin{tabular}{|c|c|c|}
\hline No & Course Title & Course Description \\
\hline 1. & Karawitan & $\begin{array}{l}\text { This course gave students the ability to play basic Surakarta style Javanese gamelan } \\
\text { instruments, individually and in groups, for simple music. }\end{array}$ \\
\hline 2. & Tembang & This course gave students the ability to sing simple Surakarta style Javanese song. \\
\hline & Pakeliran & $\begin{array}{l}\text { This course gave students basic technical skills to play the Surakarta style shadow } \\
\text { puppet and related elements of puppet mastering. }\end{array}$ \\
\hline & Tari & This course gave students basic Surakarta style Javanese dance technique. \\
\hline & Ethnomusicology & This course gave students the basic knowledge of Nusantara ethnomusicology. \\
\hline & Batik & This course gave students basic techniques to make batik in a simple way. \\
\hline & Kriya & $\begin{array}{l}\text { This course gave students basic techniques to make simple crafts from wood, } \\
\text { leather, and metal. }\end{array}$ \\
\hline
\end{tabular}

3.1.2. 12-month program, Semester 1

\begin{tabular}{|l|l|l|}
\hline No & Course Title & Course Description \\
\hline 1 & Karawitan & $\begin{array}{l}\text { This course gave students the ability to play basic music using simple Surakarta style } \\
\text { Javanese gamelan instruments, individually and in groups. }\end{array}$ \\
\hline 2 & Tembang & This course gave students the ability to sing simple Surakarta-style Javanese songs. \\
\hline 3 & Pakeliran & $\begin{array}{l}\text { This course gave students basic technical skills to play the Surakarta style shadow } \\
\text { puppet and related elements of the show. }\end{array}$ \\
\hline 4 & Tari & This course gave students basic Surakarta style Javanese dance techniques \\
\hline 5 & Etnomusikologi & This course gave students the basic knowledge of Nusantara Ethnomusicology. \\
\hline 6 & Batik & This course gave students basic technical skills in making simple batik. \\
\hline 7 & Kriya & $\begin{array}{l}\text { This course gave students basic technical skills to make crafts from wood, leather, } \\
\text { and metal in a simple way. }\end{array}$ \\
\hline
\end{tabular}

\subsubsection{2-month program, Semester 2}

\begin{tabular}{|c|c|c|}
\hline No & Course Title & Course Description \\
\hline 1 & Karawitan & $\begin{array}{l}\text { This course gave students advanced technical skills in playing Surakarta-style } \\
\text { Javanese gamelan instruments, individually and in groups, with a more complex } \\
\text { level of gending. }\end{array}$ \\
\hline 2 & Tembang & $\begin{array}{l}\text { This course gave students the ability to sing Surakarta-style Javanese song to be } \\
\text { sung in a gending. }\end{array}$ \\
\hline 3 & Pakeliran & $\begin{array}{l}\text { This course gave students knowledge in continuing to play the Surakarta style } \\
\text { puppets and related performances that werecombined with the music. }\end{array}$ \\
\hline 4 & Tari & $\begin{array}{l}\text { This course gave students the ability to perform Surakarta style Javanese dance } \\
\text { with more complicated material. }\end{array}$ \\
\hline 5 & Ethnomusicology & $\begin{array}{l}\text { This course gave students advanced skills and knowledge about the more complex } \\
\text { Nusantara ethnomusicology. }\end{array}$ \\
\hline 6 & Batik & This course gave students advanced skills in making the more detailed batik. \\
\hline 7 & Kriya & $\begin{array}{l}\text { This course gave students more detailed and complex technical abilities in making } \\
\text { crafts from wood, leather, and metal. }\end{array}$ \\
\hline
\end{tabular}

Some supporting activities help the learning process in order to get the best results were in the form of joint musical training and Indonesian learning classes. Joint musical training was done outside the classroom to get better results. As for infrastructure in the classroom were in the form of adequate learning equipment, gamelan sets, shadow puppets, and air-conditioned rooms. Learning outside the classroom was supported by the existence of hotspot facilities in the campus area, theater area, stage, training room, and sports facilities.

\subsection{Indonesian Language Learning uses Art and Culture Media}

Indonesian language learning was also packed in arts and culture courses. Indirectly Darmasiswa students not only learned arts and culture but also got additional Indonesian language material. In this way their Indonesian vocabulary would also increase. Following were some of the study programs that Darmasiswa students were interested in.

Indonesian language learning was also packed in arts and culture courses. Indirectly Darmasiswa students not only learned arts and culture but also got additional Indonesian language material. In this way their Indonesian vocabulary would also increase. Following were some of the study programs that Darmasiswa students were interested in.

\subsubsection{Puppet mastering}

Actually there were many learning models that were developed in the art of puppetry. This program had a lot of material that could be taught to Darmasiswa students, according to the situation and needs of the participants. 
But most Darmasiswa students chose programs that were considered easy to follow. Puppetry at the Surakarta Indonesian Art Institute had not been much in demand by foreign students. Most students were a bit afraid to enter this department because they thought they had to be able to perform at the end of the semester. Even though it was actually not like that, the study program had made RPS (regulation) which was not difficult for Darmasiswa students. This course gave students advanced technical skills to play the Surakarta style puppets and the elements of the performance that were applied to the accompanying music.

The introduction of puppet characters was an interesting learning model of puppetry program. This learning model was introducing familiar puppet figures known in the world. For example the legendary Mahabarata story. To attract Darmasiswa participants, teaching Mahabarata stories used pictures of puppet characters. Darmasiswa participants wereinvited to the puppetry laboratory. In the puppetry laboratory they were introduced directly to puppet figures. Students were also introduced to the characters of each puppet figure. To increase the ability in speaking Indonesian, the instructors exemplified the speaking manner and style of each character. At the end of the semester an evaluation was held to find out the percentage of students absorbing the material.

\subsubsection{Batik}

The Batik Program was one of the programs offered to Darmasiswa students. This study program was an attraction, considering that many Darmasiswa students wanted to learn about batik. The learning model in the Batik Program was designed attractively.Lectures were mostly done outside the classroom because this program placed more emphasis on practice material. The material began with the history of batik up to the process of batik making. The Batik program was introduceing the basic ingredients of batik making, motifs, and the process of batik making. The process of batik making was packaged in an interesting way so that Darmasiswa students felt comfortable taking part in lectures until the end of the semester. At the end of the semester the evaluation assignment was given, for example, students arranged a batik pattern. Then, the patternwais completed into a piece of batik cloth. Surakarta was one of the famous batik cities. In Laweyan stood Kampung Batik, which was very well known since ancient times until this decade. In this Kampung Batik visitors could witness firsthand how to make batik. Likewise Darmasiswa participants were invited to practice batik making in Kampung Laweyan. This program effectively introduced the culture of batik to foreign countries. Of course this would have a very significant effect on foreign tourists, given that there were still very few tourists visiting Surakarta. The following was the documentation during the batik learning process.

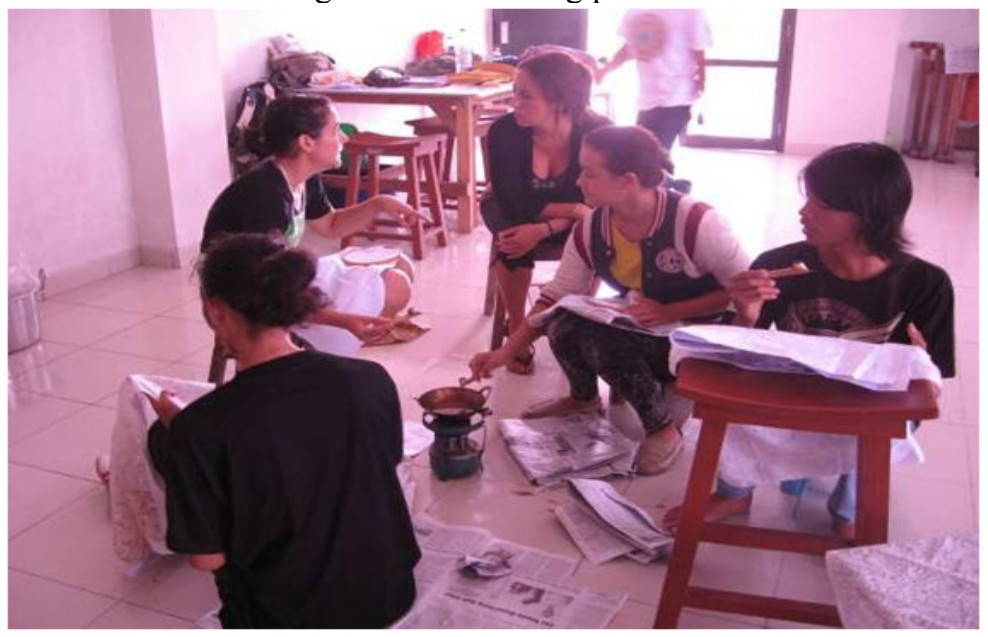

(Documentation of KUI ISI Surakarta, 2014)

\subsubsection{Karawitan}

Karawitan was one of the programs that attract participants of Darmasiswa program. Abroad, places that facilitatedkarawitanlearning were still rare. One of Darmasiswa participants shared their experience, that to learn karawitan they had to travel about 2 hours from home. This course gave students the basic ability to play instruments for Surakarta style gamelan, both individually and in groups. The learning model in the Karawitan program attracted the interest of Darmasiswa participants. In addition to regular classes held in class, there were also practice classes for students to take. In this practice class, Darmasiswa participants played Javanese gamelan instruments. Because ISI Surakarta was in Central Java, the gamelan instruments taught were the Surakarta style Javanese gamelan.

Initially, the instructor assessed the ability of Darmasiswa participants to play gamelan.If the ability was considered sufficient, Darmasiswa participants played both in groups and individually. Before starting to play gamelan, students were first introduced to the names and types of existing gamelan. Participants were asked to play each of these instruments. At the end of the semester the learning process was evaluated. At that moment, the instructorsexemined the ability of the participants in playing gamelan. Usually their gamelan playings were 
no less great than Indonesian people. Upon returning from Indonesia, it was hoped that Darmasiswa participants could teach Javanese music playing in their respective countries. Indonesia's diverse culture was the pride of the people of Indonesia. The following were documentation images during the learning process in the Karawitan Program.

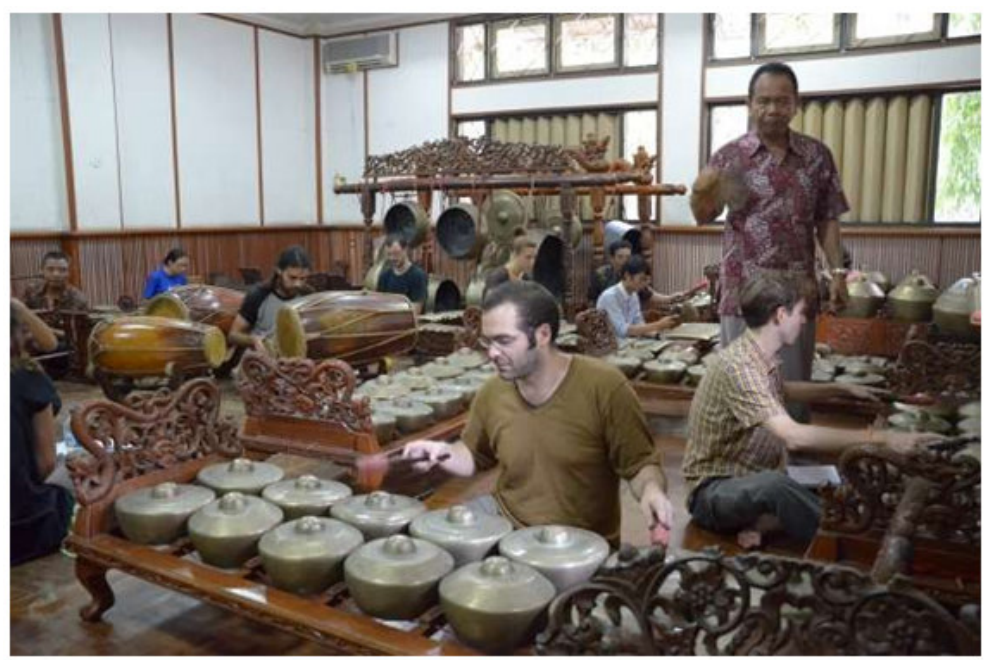

(Documentation of KUI ISI Surakarta, 2014)

\subsubsection{Dance Program}

Indonesia had a wide range of arts and culture. One of them was dance. The number of dances in Indonesia could not be counted on our fingers.Because the number of Indonesian traditional dances was indeed extraordinary. This was a very amazing fact. Like other art colleges, ISI Surakarta also prepareda Dance Program for Darmasiswa program participants. This program had prepared an easier RPS so that Darmasiswa students could take it. This course gave students knowledge of basic Surakarta style Javanese dance. The learning model in this program was very interesting because there were many practice classes. Before practicing the dances, students were first taught theories. The students were very enthusiastic in imitating the movements of dance instructors. At the end of the semester a dance evaluation was held which the results wereamazing the audience. The Darmasiswa participants danced gracefully. The aim of this program was for Darmasiswa students to bring home the dancing skills they learned in Indonesia to their country. The following was a picture of the documentation when a student was joining a group in performing a dance.

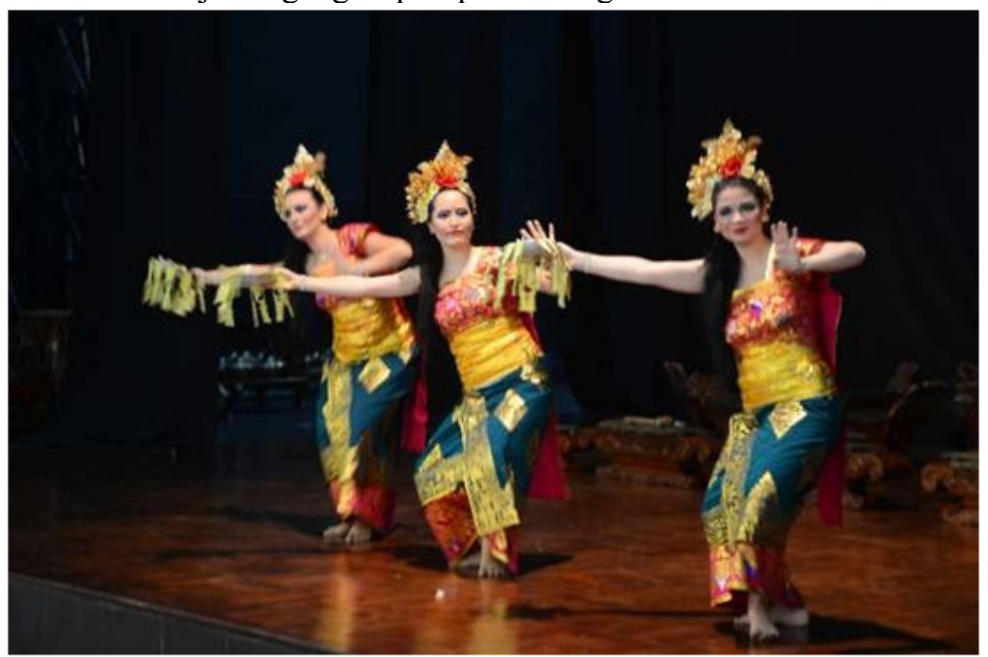

(Documentation of KUI ISI Surakarta, 2014)

\subsubsection{Ethnomusicology}

This course gave advanced knowledge about the more complex ethnomusicology of the Nusantara. This learning model was even more interesting because students were usually invited to undergo field studies. Discussion on ethnomusicology meant in-depth discussion of the very diverse local music of the Nusantara. Almost all regions of Indonesia had distinctive traditional music. The music was a feature that described the surrounding community. This subject was also much sought after by Darmasiswa participants in several art universities in Indonesia, because they would learn traditional music. While materials in musicalclasses abroad mostly discussed modern music. If both were compiled, it would produce a very beautiful work. Beauty could not be 
separated from a work of art.

\subsubsection{Crafts}

This course gave students more detailed and complex technical skills in making crafts from wood, leather, and metal. The Craft Program was also found to be the destination of several students who participated in the darmasiswa program. In this program students learned about various handicrafts from the basic materials of wood, leather, and metal. The learning was not boring because students took many practical classes. Practical classes were guided by instructors and technicians. They learned various interesting wood carvings; for example, making wood carvings that were characteristic in the city of Surakarta as a basic technique. The learning process was quite fun because students were guided directly in practicing carving techniques with materials from metal, wood, or leather. At the time of evaluating the final project, participants of the students made various carvings that were exhibitedlater. The Indonesian government hoped that after returning from the Darmasiswa program, to their respective countries, the participants would share their knowledge in Indonesia. This was an efficient way to introduce Indonesian arts and culture to the international community. The following was the documentation picture during the learning process.

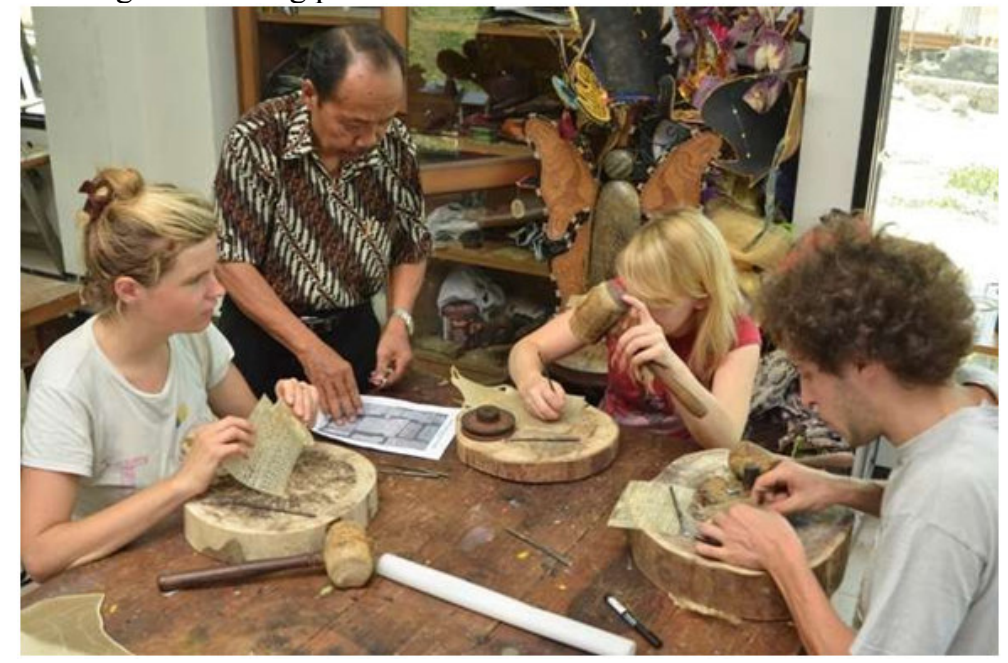

(Documentation of KUI ISI Surakarta, 2014)

\subsection{Development of Cooperative Learning Models Through Indonesian Language Materials}

BIPA instructors patiently teached writing started from simple things. For example, telling about family and country of origin in Indonesian, using simple sentences. The sentence structure made by Darmasiswa participants was indeed not correct, but at least they could already write in Indonesian. Correct sentence structure was indeed rather difficult because instructors must explain the subject and the predicate. Foreign students were also usually still wrong in using the word choice (diction). This was understandable because it took a long time to learn a language.

Indonesian language learning also emphasized the ability to be able to communicate with people. This communication was packaged in the form of a presentation. To encourage students participating in class communication, they were asked to introduce themselves in Indonesian. It was starting from the name, place and date of birth, hobbies, country of origin, boarding house, and so on. BIPA instructors patiently corrected if there were any mistakes in the choice of words. This program also indirectly helped students' speaking skills. BIPA usually had prepared several learning media that were deemed appropriate so that the learning process could run optimally. Some learning mediazwere interesting alternatives to be taught to foreign students. Some of the media include:

\subsubsection{Compose stories about daily activities}

This method was suitable for helping students made small notes of each activity they do. Recording started from the things done when they woke up in the morning to the next activities. The vocabulary used from daily activities would help students in their language learning. In the end students would be quite adept at communicating using Indonesian. The cooperative learning model was a place for students to study in groups. Usually foreign students (Darmasiswa) looked for a place to stay (boarding) in an environment where there were friends from their country. From there, the students learned together and communicated with each other in Indonesian. These daily activities increased the amount of vocabulary in Indonesian language. Then it was probable that they would be proficient in Indonesian in only 3 months.

\subsubsection{Telling stories in class}

The method of telling a story in class was considered a simple method because it only told stories with a free topic. But this actually had good benefits to motivate foreign students to communicate in the classroom using 
Indonesian. At first they were asked to form groups to motivate mutual storytelling. The next task was to tell stories individually. Instructors immediately evaluated when they were telling stories. In this way, the instructor immediately provided interactive feedback.

\subsubsection{Understanding reading material related to Indonesian culture}

BIPA instructors must have the right strategy so that learning Indonesian could be attractive to foreign students. One way to do this was to take reading material about Indonesian culture. Darmasiswa students were asked to work in groups with one reading, then they were asked to retell the contents of the reading in class. The cooperative learning model helped students to learn in groups. Each group team was rewarded if they retold the reading properly. In addition to giving motivation, it also showed appreciation. This model encouraged other participants to learn to communicate better.

The cooperative learning method as a way to add Indonesian vocabulary used by BIPA instructors had proven to be effective. Students were invited to directly talk with the feedback model. The theme was created flexibly for example about the student's hobbies, activities, and trips. This method lured students to be active in communicating because there was feedback from the instructor. Basically speaking skills could be categorized into two levels, i.e. active and passive language skills. Active language skills was described as a person's ability to speak in daily communication activities. While passive ability was interpreted as a person's ability to speak only in writing, reading, but not in the form of direct conversation. Most people who were learning languages were categorized as passive language users. This meant understanding Indonesian only in reading, writing, but not being able to communicate in feedback. This was certainly also experienced by foreign students who were learning Indonesian.

BIPA learning did indeed encounter many complexities. We needed to realize that Indonesian was quite complicated for foreign students to learn. Various levels of language used become a problem that must be sought by a BIPA instructor. In addition, sources that were used as references by BIPA instructors were also still limited. BIPA instructors must be observant and creative in providing material that made it easy for foreign students to learn Indonesian. To add to the Indonesian vocabulary, it was not uncommon for BIPA instructors to bring examples of simple objects and various foods in Indonesia. This action also introduced the life of Indonesians. In overcoming the boredom of intensive learning Indonesian for three months, the instructor used interesting methods in learning. The methods were through: (1) memorizing Indonesian vocabulary methods, (2) methods of telling stories about habits, hobbies, activities, (3) listening methods from BIPA instructors, (4) methods of understanding light reading texts, and (5) method of visiting several places in the city.

\section{CONCLUSION}

The Darmasiswa Program was one of the programs to introduce Indonesian culture to foreign countries through selected foreign students. The learning process used Indonesian as the language of instruction. The Indonesian learning process had obstacles that were not easily overcome because the intensive study time was only 3 months. To overcome these obstacles, instructors for foreign students (BIPA) used models, methods, media to help smooth the learning process. One model used was a cooperative learning model. This model was expected to help students learn Indonesian effectively and efficiently. After researching, it was proven that this model was more appropriate to be adopted in the Indonesian language learning process.

\section{REFERENCES}

Guntur.2010. Menuju SarjanaSujaeneng Budi: Pendidikan Karakter DiInstitut Seni Indonesia Surakarta. (Makalah). P3AI:ISISurakarta.

Sugihastuti. 2000.Bahasa Laporan Penelitian. Yogyakarta: PustakaPelajar.

Winaputra, Udin S. 1997. Konsep dan Model Pengembangan Kurikulum Program Pendidikan dan Pelatihan. (Makalahdisajikan dalam : Diskusi danLokakrya Pengembangan Kurikulum ProgramPendidikan dan Pelatihan-Universitas Terbuka.) 